\title{
Seroprevalence of Toxoplasma gondii infection in goats from the south-west region of Poland and the detection of T. gondii DNA in goat milk
}

\author{
Jacek Sroka ${ }^{1}$, Paweł Kusyk ${ }^{1}$, Ewa Bilska-Zając ${ }^{1}$, Jacek Karamon ${ }^{1}$, Jacek Dutkiewicz ${ }^{2}$, Angelina Wójcik-Fatla ${ }^{2}$, \\ Violetta Zając ${ }^{2}$, Krzysztof Stojecki ${ }^{1}$, Mirosław Różycki ${ }^{1}$ and Tomasz Cencek ${ }^{1}$
}

\author{
${ }^{1}$ Department of Parasitology and Invasive Diseases, National Veterinary Research Institute, Pulawy, Poland; \\ ${ }^{2}$ Department of Health Biohazards and Parasitology, Institute of Rural Health, Lublin, Poland
}

\begin{abstract}
Toxoplasma gondii (Nicolle et Manceaux, 1908) is an obligatory intracellular protozoan parasite prevalent in animals and humans worldwide having medical and veterinary importance on account of causing abortion or congenital disease in intermediate hosts, including man. Since T. gondii has already been identified in the milk of goats, Capra aegagrus hircus (Linnaeus), the possibility of acquiring infection by ingesting unpasteurised goat milk should be taken into consideration. Thus, the aim of the present study was to determine the presence of $T$. gondii DNA in goat milk. First, 73 goats (females) from 36 farms located in Poland were examined serologically by direct agglutination test (DAT) to estimate the $T$. gondii serological status. Milk samples from 60 selected lactating females were examined for the presence of $T$. gondii DNA by Real time PCR and nested PCR (B1 gene). To estimate the clonal type of detected T. gondii, multiplex PCR was performed using 6 markers. In DAT, positive results were found in $70 \%$ of 73 goats. Among examined 60 milk samples, $65 \%$ were positive in Real time PCR and 43\% in nested PCR. It is noteworthy that 11 samples positive in PCR were collected from seronegative goats. The multilocus PCR analysis mostly revealed the occurrence of genotype III, which is relatively rare in Europe. The recorded high prevalence of anti-Toxoplasma antibodies in tested goats (70\%), associated with a high prevalence of T. gondii DNA in goat milk samples (65\%), indicates a potential risk of the parasite transmission through goat milk ingestion.
\end{abstract}

Keywords: toxoplasmosis, DAT, PCR, genotyping, serology

Toxoplasma gondii (Nicolle et Manceaux, 1908) is an obligatory intracellular protozoan parasite that causes infection in humans and in many species of wild and domestic animals. Infection in humans with $T$. gondii may pose a severe medical problem in a congenital form, causing cerebral and ocular damage in newborns, and as an acquired infection in immunocompromised individuals (Dubey and Beattie 1988). Humans usually become infected by ingestion of undercooked meat containing tissue cysts, or by consumption of food or water contaminated by oocysts excreted by cats.

Tachyzoites of $T$. gondii have already been identified and isolated from the milk of goats, Capra aegagrus hircus (Linnaeus), and infections of goats have been noted worldwide. Therefore, the possibility of acquiring infection by ingesting unpasteurised goat milk should be taken into consideration (Mancianti et al. 2013, Dubey et al. 2014). In fact, cases of clinical toxoplasmosis have been reported in humans after drinking unpasteurised goat's milk (Dubey et al. 2014). Fresh dairy products made from raw goat milk could be also a potential source of infection with $T$. gondii (see Walsh et al. 1999).

The aim of the present study was to determine the presence of $T$. gondii DNA in milk samples of goats from Poland.

\section{MATERIALS AND METHODS}

Animals. The examined goats originated from the south-western part of Poland, the traditional region of goat breeding. In total, 73 females aged of $0.5-20$ years $($ mean $=4.6, \mathrm{SD}=3.9)$ from 36 farms were examined serologically to estimate serological status.

Serological examination. Blood was taken from the goats by jugular punctures and allowed to clot at room temperature. After centrifugation, serum was stored at $-20^{\circ} \mathrm{C}$ until testing. Antibodies against $T$. gondii were detected by commercial direct agglutination test (DAT) (Toxo-Screen DA, bioMerieux, Marcy-L'Étoile, France) in accordance with manufacturer's instructions. A titre of 1:40 was considered as evidence of exposure to T. gondii.

Goat milk examination. Milk samples $(4 \mathrm{ml})$ were collected from 60 lactating females by manual milking of teats and stored

Address for correspondence: J. Sroka, Department of Parasitology and Invasive Diseases, National Veterinary Research Institute, Al. Partyzantow 57, 24-100 Pulawy, Poland. Phone: +48 818893040; Fax: +48 81 8862595; E-mail: jacek.sroka@piwet.pulawy.pl 
frozen. Before analysis, the milk samples were centrifuged, and to avoid interference by casein, pellet of milk was treated with $200 \mu 1 \mathrm{TE}(1 \mathrm{mM}$ EDTA, $10 \mathrm{mM}$ Tris-HCl $(\mathrm{pH}=7.6)$ (Sigma-Aldrich Co., St. Louis, USA) and $300 \mu 10.5$ M EDTA (pH 8) (Sigma-Aldrich), resuspended and centrifuged at 3,000 $\mathrm{g}$ for 10 min. Next, the milk samples were diluted in $200 \mu 1$ of PBS, according to the method described by Psifidi et al. (2010).

DNA from milk samples was extracted using QIAamp DNA mini kit (Qiagen, GmbH, Hilden, Germany) according to the manufacturer's instruction. Real time PCR was performed according to the method described by Lin et al. (2000) using commercial master mix QI Supermix (Bio-Rad, Hercules, California, USA). The amplification was carried out in a thermal cycler CFX-96 (Bio-Rad).

Detection of the DNA of $T$. gondii was performed by amplification of 35-fold-repetitive $B 1$ fragment gene in nested PCR, according to the method by Grigg and Boothroyd (2001). To estimate the clonal type for $B 1$ gene positive samples, multilocus PCR was performed using markers SAG1, SAG2 (5'-SAG2 and 3'-SAG2), SAG3 and GRA6 according to method described by $\mathrm{Su}$ et al. (2010). Nested PCR and Multilocus PCR were carried out in a C1000 Thermal Cycler (Bio-Rad). In each PCR tests, as positive controls isolates of the DNA of $T$. gondii of RH (type I), ME49 (type II) and C56 (type III) strains were used, nuclease-free water was used as the negative control.

DNA sequencing of amplicons was performed using ABI PRISM 310 Genetic Analyzer (Applied Biosystems, Inc., Foster City, CA, USA), with the use of Abi Prism Big Dye Terminator v. 3.1. Cycle Sequencing Kits and Big Dye XTerminator Purification Kit (Applied Biosystems). Sequences were analysed using BioEdit and MEGA 7 software, and compared with the NCBI database using Blast.

The results were analysed with $\chi^{2}$ test, using STATISTICA v. 5.1 package (Statsoft, Tulsa, OK, USA).

\section{RESULTS}

The positive results in DAT were found in 51 of 73 $(70 \%)$ tested goats (Table 1). Among positive results $21.5 \%, 17.5 \%$ and $61 \%$ were detected in titre ranges $40-180,540-4,000$ and $\geq 6,000$, respectively.

Among the examined 60 milk samples, 39 (65\%) were positive in Real time PCR and 26 (43\%) in nested PCR. It

Table 1. Summary of direct agglutination test (DAT) and PCR results for Toxoplasma gondii in goats.

\begin{tabular}{|c|c|c|c|c|c|}
\hline \multirow{2}{*}{ Farm No. } & \multirow{2}{*}{$\begin{array}{c}\text { No. of } \\
\text { animals }\end{array}$} & \multirow{2}{*}{ Age (years) } & \multicolumn{3}{|c|}{ Results (No. of positive/No. of examined) } \\
\hline & & & DAT (titre) & Real time PCR & Nested PCR (B1) \\
\hline 1 & 2 & $5 ; 3$ & 6,$000 ; 0$ & $0 ; 1$ & $0 ; 1$ \\
\hline 2 & 3 & $5 ; 2 ; 2$ & $0 ; 0 ; 18,000$ & $1 ; 1 ; 1$ & $0 ; 0 ; 0$ \\
\hline 3 & 2 & $6 ; 3$ & 18,$000 ; 0$ & $1 ; 0$ & $0 ; 0$ \\
\hline 4 & 2 & $3 ; 3$ & 6,$000 ; 6,000$ & $0 ; 1$ & $0 ; 0$ \\
\hline 5 & 2 & $3 ; 1$ & $0 ; 0$ & $\mathrm{n} / \mathrm{e} ; 1$ & $\mathrm{n} / \mathrm{e} ; 1$ \\
\hline 6 & 1 & 3 & 54,000 & 0 & 0 \\
\hline 7 & 3 & $3 ; 3 ; 5$ & $0 ; 0 ; 18,000$ & $1 ; 1 ; 0$ & $0 ; 0 ; 0$ \\
\hline 8 & 1 & 8 & 4,000 & 1 & 1 \\
\hline 9 & 2 & $3 ; 3$ & 6,$000 ; 54,000$ & $1 ; 1$ & $0 ; 1$ \\
\hline 10 & 1 & 5 & 180 & 0 & 0 \\
\hline 11 & 3 & $5 ; 6 ; 2$ & $40 ; 18,000 ; 18,000$ & $0 ; 0 ; 1$ & $0 ; 0 ; 1$ \\
\hline 12 & 1 & 6 & 180 & 1 & 0 \\
\hline 13 & 1 & 15 & 0 & 1 & 1 \\
\hline 14 & 1 & 2 & 0 & 0 & 0 \\
\hline 15 & 1 & 16 & 18,000 & 1 & 1 \\
\hline 16 & 3 & $5 ; 4 ; 2$ & 4,$000 ; 40 ; 0$ & $1 ; \mathrm{n} / \mathrm{e} ; \mathrm{n} / \mathrm{e}$ & $1 ; \mathrm{n} / \mathrm{e} ; \mathrm{n} / \mathrm{e}$ \\
\hline 17 & 1 & 1.5 & 0 & $\mathrm{n} / \mathrm{e}$ & $\mathrm{n} / \mathrm{e}$ \\
\hline 18 & 6 & $5 ; 3 ; 2 ; 1 ; 1 ; 1$ & 6,$000 ; 18,000 ; 54,000 ; 6,000 ; 4,000 ; 6,000$ & $0 ; 0 ; 1 ; 0 ; 1 ; 1$ & $0 ; 1 ; 1 ; 0 ; 1 ; 0$ \\
\hline 19 & 1 & 5 & 6,000 & 1 & 1 \\
\hline 20 & 2 & $2 ; 3$ & $0 ; 6,000$ & $1 ; \mathrm{n} / \mathrm{e}$ & $1 ; \mathrm{n} / \mathrm{e}$ \\
\hline 21 & 3 & $13 ; 2 ; 1$ & 6,$000 ; 180 ; 4,000$ & $0 ; 1 ; 1$ & $1 ; 1 ; 1$ \\
\hline 22 & 5 & $4 ; 2 ; 10 ; 5 ; 5$ & 4,$000 ; 0 ; 6,000 ; 180 ; 4,000$ & $0 ; \mathrm{n} / \mathrm{e} ; 1 ; 1 ; 1$ & $0 ; \mathrm{n} / \mathrm{e} ; 1 ; 1 ; 0$ \\
\hline 23 & 2 & $1 ; 3$ & $540 ; 54,000$ & $1 ; 0$ & $0 ; 0$ \\
\hline 24 & 1 & 10 & 6,000 & 1 & 0 \\
\hline 25 & 1 & 5 & 54,000 & 1 & 0 \\
\hline 26 & 2 & $0.5 ; 0.5$ & $0 ; 0$ & $\mathrm{n} / \mathrm{e} ; \mathrm{n} / \mathrm{e}$ & $\mathrm{n} / \mathrm{e} ; \mathrm{n} / \mathrm{e}$ \\
\hline 27 & 1 & 0.5 & 0 & $\mathrm{n} / \mathrm{e}$ & $\mathrm{n} / \mathrm{e}$ \\
\hline 28 & 2 & $1 ; 7$ & $0 ; 40$ & $1 ; 0$ & $0 ; 1$ \\
\hline 29 & 1 & 1 & 6,000 & 0 & 0 \\
\hline 30 & 3 & $4 ; 14 ; 5$ & $0 ; 6,000 ; 54,000$ & $1 ; 1 ; 1$ & $0 ; 0 ; 1$ \\
\hline 31 & 3 & $10 ; 10 ; 10$ & $40 ; 4000 ; 6,000$ & $0 ; 1 ; \mathrm{n} / \mathrm{e}$ & $0 ; 1 ; \mathrm{n} / \mathrm{e}$ \\
\hline 32 & 1 & 20 & 6,000 & 0 & 1 \\
\hline 33 & 2 & $6 ; 5$ & 18,$000 ; 18,000$ & $0 ; 1$ & $0 ; 1$ \\
\hline 34 & 4 & $0.5 ; 0.5 ; 6 ; 6$ & $0 ; 0 ; 180 ; 0$ & $\mathrm{n} / \mathrm{e} ; \mathrm{n} / \mathrm{e}, 1 ; 1$ & $\mathrm{n} / \mathrm{e} ; \mathrm{n} / \mathrm{e}, 1 ; 1$ \\
\hline 35 & 2 & $4 ; 0.5$ & 1,$620 ; 40$ & $0 ; \mathrm{n} / \mathrm{e}$ & $0 ; \mathrm{n} / \mathrm{e}$ \\
\hline 36 & 1 & 8 & 40 & 1 & 1 \\
\hline Total & 73 & 4.6 (mean); $3.9(\mathrm{SD})$ & $51 / 73(70 \%)$ & $39 / 60(65 \%)$ & $26 / 60(43 \%)$ \\
\hline
\end{tabular}

$\mathrm{n} / \mathrm{e}$ - not examined - no milk samples available. 
Table 2. Results of genotyping of Toxoplasma gondii detected in goat milk.

\begin{tabular}{lcccccc}
\hline $\begin{array}{l}\text { Total } \\
\text { No. of } \\
\text { milk } \\
\text { samples }\end{array}$ & SAG1 & 3'SAG2 & 5'SAG2 & SAG3 & BTUB & GRA6 \\
\hline 1 & & & & & & \\
2 & $\mathrm{n} / \mathrm{a}$ & $\mathrm{I} / \mathrm{III}$ & $\mathrm{III}$ & $\mathrm{III}$ & $\mathrm{n} / \mathrm{a}$ & $\mathrm{III}$ \\
2 & $\mathrm{n} / \mathrm{a}$ & $\mathrm{I} / \mathrm{III}$ & $\mathrm{III}$ & $\mathrm{n} / \mathrm{a}$ & $\mathrm{I} / \mathrm{III} *$ & $\mathrm{n} / \mathrm{a}$ \\
1 & $\mathrm{n} / \mathrm{a}$ & $\mathrm{I} / \mathrm{III}$ & $\mathrm{III}$ & $\mathrm{n} / \mathrm{a}$ & $\mathrm{n} / \mathrm{a}$ & $\mathrm{n} / \mathrm{a}$ \\
1 & $\mathrm{II} / \mathrm{III} \#$ & $\mathrm{n} / \mathrm{a}$ & $\mathrm{n} / \mathrm{a}$ & $\mathrm{III}$ & $\mathrm{n} / \mathrm{a}$ & $\mathrm{n} / \mathrm{a}$ \\
1 & $\mathrm{n} / \mathrm{a}$ & $\mathrm{n} / \mathrm{a}$ & $\mathrm{III}$ & $\mathrm{n} / \mathrm{a}$ & $\mathrm{n} / \mathrm{a}$ & $\mathrm{III}$ \\
3 & $\mathrm{II} / \mathrm{III} * *$ & $\mathrm{n} / \mathrm{a}$ & $\mathrm{n} / \mathrm{a}$ & $\mathrm{n} / \mathrm{a}$ & $\mathrm{n} / \mathrm{a}$ & $\mathrm{n} / \mathrm{a}$ \\
6 & $\mathrm{n} / \mathrm{a}$ & $\mathrm{I} / \mathrm{III}$ & $\mathrm{n} / \mathrm{a}$ & $\mathrm{n} / \mathrm{a}$ & $\mathrm{n} / \mathrm{a}$ & $\mathrm{n} / \mathrm{a}$ \\
2 & $\mathrm{n} / \mathrm{a}$ & $\mathrm{n} / \mathrm{a}$ & $\mathrm{III}$ & $\mathrm{n} / \mathrm{a}$ & $\mathrm{n} / \mathrm{a}$ & $\mathrm{n} / \mathrm{a}$ \\
6 & $\mathrm{n} / \mathrm{a}$ & $\mathrm{n} / \mathrm{a}$ & $\mathrm{n} / \mathrm{a}$ & $\mathrm{III}$ & $\mathrm{n} / \mathrm{a}$ & $\mathrm{n} / \mathrm{a}$ \\
\hline
\end{tabular}

$\mathrm{n} / \mathrm{a}$ - product not amplified; I-III - clonal lineage; GenBank accession numbers: * KY634427, KY634428; ** KY634429; *** KY634421KY634426; \# KY634430.

is noteworthy that 11 samples positive in PCR were collected from seronegative goats.

Analysis of genotyping showed that amplification in used markers (SAG1, 3'SAG2, 5'SAG2, SAG3, BTUB and GRA6) was possible for selected $B 1$ gene-positive sample. Two samples were positive in four and three markers, another four samples amplified in two markers. For the remaining 17 samples, the positive reaction was obtained only in one marker (Table 1). No new single-nucleotide polymorphisms (SNPs) were found. For 14 samples only type III lineage was determined. Eleven samples had alleles type III at the 5'SAG2 locus, four samples at the SAG3 locus and seven samples at the GRA6 locus. Seven samples had alleles types I/III at the 3'SAG2 locus and one at the BTUB locus. Two samples had alleles II/III types at the SAG1 locus (Table 2).

\section{DISCUSSION}

The present study showed $71 \%$ of seropositive results among the tested goats, this is at the upper limit of the results from various European countries. The results obtained in the present study are meaningful not only because of high seropositivity, but also because of a very high proportion $(61 \%)$ of strong reactions with titres 6,000 and higher. High seropositivity reported in goats worldwide (Iovu et al. 2012, Djokic et al. 2014) indicates that goats appear to be susceptible to $T$. gondii infection. Clinical toxoplasmosis with an abortion and neonatal mortality, as well as fatal cases of acute toxoplasmosis in goats were also reported (Dubey and Beattie 1988, Masala et al. 2007, Mancianti et al. 2013). In Poland, about 30-100\% of goats are exposed on T. gondii (Michalski and Platt-Samoraj 2004, Czopowicz et al. 2011). The examined goats were most often kept in backyard systems, less frequently in large specialised herds or for hobby purposes. Goats were usually stabled together with other animals, including cats. Thus, contaminated pasture and water seem to be the main sources of infection with $T$. gondii, which was also indicated by others authors (Deng et al. 2016).
In the present study, the DNA of T. gondii was found by PCR in $43-65 \%$ of goat milk samples. The positive PCR results were found also for 11 milk samples from seronegative goats, which can be explained by the initial phase of infection and undetectable level of specific antibodies. The PCR results in the present study are much higher than recently reported in Poland (3\%) by Cisak et al. (2017). A lower percentage $(6 \%)$ was obtained in Brazil (Bezerra et al. 2015) and Italy (13\%) (Mancianti et al. 2013). A relatively high prevalence (33\%) was recorded by Spišák et al. (2010) in Slovakia. The presence of DNA of T. gondii in goat milk is not equivalent with the viability of the parasite, but drinking unpasteurised goat milk was found to be a risk factor for acquired toxoplasmosis in pregnant women in Europe (Cook et al. 2000) and in the United States (Dubey et al. 2014). Moreover, the results of experiments by Dubey et al. (2014) showed that T. gondii can be excreted intermittently in goat's milk, and the parasite can also survive in cheese made from unpasteurised, cold goat's milk.

In the present study, bioassay was not performed and none of viable tachyzoites were isolated from the milk samples. Therefore, it is possible that tachyzoites in milk (all or in part) could be inactivated among others by specific antibodies whose high level (titre 6,000 and higher) at the large number of examined animals was found. However, the presence of viable tachyzoites of $T$. gondii in the milk of chronically infected goats can be due to possible resurgence of tissue with cysts tachyzoites of $T$. gondii which can be excreted in the milk during physiological decrease in the peripartum immunity (Silva et al. 2010). Since goat milk and milk product are often used unpasteurised, it should be taken into consideration that the presence of the DNA of T. gondii in milk samples can also increases the possibility of live parasite transmission.

Most of strains of T. gondii detected in humans and animals in Europe are one of three types of clonal lineages (I, II or III), but atypical strains were also found (Ajzenberg 2010). Type II strains are the most common in chronical infection, whereas type III strains are responsible for infection primarily in domestic animals. In France, type II was found in more than $90 \%$ of human congenital toxoplasmosis, but also in all isolates originating from a large number of animal species (Ajzenberg et al. 2002, Dardé 2008). However, studies in Portugal, Spain and the Slovak Republic indicate that type III or type I may be more frequent in these countries (Fuentes et al. 2001, de Sousa et al. 2006, Turčeková et al. 2013). Moreover, Berger-Schoch et al. (2011) reported that sheep in Switzerland were infected with $T$. gondii with clonal type II, but cattle were infected with the clonal types I or III, or atypical T. gondii. RFLP analyses of SAG2 locus carried on protected wildlife in the Tatra National Park, Slovakia, revealed that 44\% of isolates of $T$. gondii were characterised as genotype III, $39 \%$ were represented by genotype II and $17 \%$ isolates belonged to genotype I (Turčeková et al. 2014).

In our survey we have confirmed mainly genotype III of T. gondii in genotyped samples. However, it was not possi- 
ble to distinguish types I and III or II and III (Table 2). These results can also indicate a possible combination of different alleles, not type III alone. Genotyping by one marker only (possible for the majority of samples) could also be insufficient for definitive analysis. Unsuccessful PCR amplification for all six tested markers may be due, at least in part, to the low amount of DNA, which is not quite suitable for genotyping. Data concerning typing of the DNA of $T$. gondii isolated from goat milk are scarce. In another study, by Mancianti et al. (2013) among ten PCR positive samples, genetic characterisation revealed the occurrence of genotype III from seven samples, genotype I from one sample, and atypical genotypes from two samples.

The present study focused on the assessment of potential risk associated with the ingestion of goat milk. To the best of to our knowledge, this is the first report on the genetic characterisation of $T$. gondii detected in goat milk in Poland.

Considering the fact that goats can represents an important source of milk, they seem to play a very important role in the epidemiology of human toxoplasmosis. In order to decrease the risk by avoiding ingestion of raw goat milk, appropriate health education is needed worldwide.

The recorded high prevalence of anti-Toxoplasma antibodies in goat blood $(70 \%)$, with a high percentage of titre 6,000 and above, associated with a high prevalence of $T$. gondii DNA in goat milk (65\%), indicates a potential risk of the transmission of Toxoplasma through raw milk ingestion. Current consumer recommendations to avoid drinking raw milk, or eating fresh dairy products made from raw milk seems to be accurate in the light of the findings of the present study. Obtained data can also be useful for farmers and veterinarians, to improve the methods of management and prevention on goat farms.

Acknowledgements. The authors express special thanks to Halina Majer (Veterinary Clinic 'TRIOVET', Jastrzębie-Zdrój, Poland) for assistance in providing samples of goat milk and sera, and to Chunlei Su (University of Tennessee, Knoxville, USA) for help in sequence analysis.

\section{REFERENCES}

AjZenberg D. 2010: Type I strains in human toxoplasmosis: myth or reality? Future Microbiology 5: 841-843.

Ajzenberg D., Bañuls A.L., Tibayrenc M., Dardé M.L. 2002: Microsatellite analysis of Toxoplasma gondii shows considerable polymorphism structured into two main clonal groups. Int. J. Parasitol. 32: 27-38.

Berger-Schoch A.E., Herrmann D.C., Schares G., Müller N., Bernet D., Gottstein B., Frey C.F. 2011: Prevalence and genotypes of Toxoplasma gondii in feline faeces (oocysts) and meat from sheep, cattle and pigs in Switzerland. Vet. Parasitol. 177: 290-297.

Bezerra M.J., Kim P.C., Moraes É.P., Sá S.G., Albuquerque P.P., Silva J.G., Alves B.H., Мota R.A. 2015: Detection of Toxoplasma gondii in the milk of naturally infected goats in the Northeast of Brazil. Transbound. Emerg. Dis. 62: 421-424.

Cisak E., Zając V. Sroka J., Sawczyn A., Kloc A., Dutkiewicz J., Wójcik-Fatla A. 2017: Presence of pathogenic rickettsiae and protozoan in samples of raw milk from cows, goats, and sheep. Foodborne Pathog. Dis. 14: 189-194.

Cook A.J.C., Gilbert R.E., Buffolano W., Zufferey J., Peterse E., Jenum P.A., Foulon W., Semprini A.E., Dunn, D.T. 2000: Sources of Toxoplasma infection in pregnant women: European multicentre case-control study. Brit. Med. J. 321: 142-147.

Czopowicz M., Kaba J., Szaluś-Jordanow O., Nowicki M. Witkowski L., Frymus, T. 2011: Seroprevalence of Toxoplasma gondii and Neospora caninum infections in goats in Poland. Vet. Parasitol. 178: 339-341.

DARDÉ M.L. 2008: Toxoplasma gondii, "new” genotypes and virulence. Parasite 15: 366-371.

Deng H, Dam-Deisz C, Luttikholt S, Maas M, Nielen M, Swart A, Vellema P, van Der Giessen J, Opsteegh M. 2016: Risk factors related to Toxoplasma gondii seroprevalence in indoor-housed Dutch dairy goats. Prev. Vet. Med. 124: 45-51.

Djokic V., Klun I., Musella V., Rinaldi L., Cringoli G., Sotiraki S., Duurkovic-Djakovic O. 2014: Spatial epidemiology of Toxoplasma gondii infection in goats in Serbia. Geospat. Hlth 8: 479-488.

Dubey J.P., BeAttie C.P. 1988: Toxoplasmosis of Animals and Man. CRC Press, Inc., Boca Raton, Florida, pp. 81-86.

Dubey J.P., Verma S.K., Ferreira L.R., Oliveira S., Cassinelli A.B., Ying Y., Kwok O.Ch, Tuo W., Chiesa O.A., JONES I.L. 2014: Detection and survival of Toxoplasma gondii in milk and cheese from experimentally infected goats. J. Food Prot. 77, 10: 1747-1753.

Fuentes I., Rubio J.M., Ramírez C., Alvar J. 2001: Genotypic characterization of Toxoplasma gondii strains associated with human toxoplasmosis in Spain: direct analysis from clinical samples. J. Clin. Microbiol. 39: 1566-1570.

Grigg M.E., Bоотhroyd J.C. 2001: Rapid identification of virulent type I strains of the protozoan pathogen Toxoplasma gondii by PCR restriction fragment length polymorphism analysis at the $B 1$ gene. J. Clin. Microbiol. 39: 398-400.

Iovu A., Gyoerke A., Mircean V., Gavrea R., Cozma V. 2012: Seroprevalence of Toxoplasma gondii and Neospora caninum in dairy goats from Romania. Vet. Parasitol. 186: 470-474.

Lin M.H., Chen T.C., Kuo T.T., Tseng C.C., Tseng C.P. 2000: Real-time PCR for quantitative detection of Toxoplasma gondii. J. Clin. Microbiol. 38: 4121-4125.

Mancianti F., Nardoni S., D'Ascenzi C., Pedonese F., Mugnaini L., Franco F., Papini R. 2013: Seroprevalence, detection of DNA in blood and milk, and genotyping of Toxoplasma gondii in a goat population in Italy. Biomed. Res. Int.: 905326.

Masala G., Porcu R., Daga C.. Denti S., Canu G., Patta C., ToLA S. 2007: Detection of pathogens in ovine and caprine abortion samples from Sardinia, Italy, by PCR. J. Vet. Diagn. Invest. 19: 96-98.

Michalski M., Platt-Samoraj A. 2004: [Extent of Toxoplasma gondii invasion in goat and sheep from the Olsztyn region.] Med. Wet. 60: 70-71. (In Polish.)

Psifidi A., Dovas C.I., Banos G. 2010: A comparison of six methods for genomic DNA extraction suitable for PCR-based genotyping applications using ovine milk samples. Mol. Cell. Probes 24: $93-98$.

Silva R.C., Silva A.V., Langoni H. 2010: Recrudescence of Toxoplasma gondii infection in chronically infected rats (Rattus novergicus). Exp. Parasitol. 125: 409-412.

de Sousa S., Ajzenberg D., Canada N., Freire L., Da Costa J.M.,Dardé M.L., Thulliez P., Dubey J.P. 2006: Biologic and molecular characterization of Toxoplasma gondii isolates from pigs from Portugal. Vet. Parasitol. 135: 133-136.

Spišák F., TurČeková L., Reiterová K., Spilovská S., DubinSKÝ P. 2010: Prevalence estimation and genotypization of Toxoplasma gondii in goats. Biologia 65: 670-674. 
Su C., Shwab E.K., Zhou P., Zhu X.Q., Dubey J.P. 2010: Moving towards an integrated approach to molecular detection and identification of Toxoplasma gondii. Parasitology 137: 1-11.

Turčeková L, Antolová D, Reiterová K, Spišák F. 2013: Occurrence and genetic characterization of Toxoplasma gondii in naturally infected pigs. Acta Parasitol. 58: 361-366.

Turčeková L, Hurníková Z, SpišÁk F, Miterpáková M, ChoVANCOVÁ M. 2014: Toxoplasma gondii in protected wildlife in the Tatra National Park (TANAP), Slovakia. Ann. Agric. Environ. Med. 21: 235-238.

Walsh C.P., Hammond S.E., Zajac A.M., Lindsay D.S. 1999 Survival of Toxoplasma gondii tachyzoites in goat milk: potential source of human toxoplasmosis. J. Eukaryot. Microbiol. 46: $73 \mathrm{~S}-74 \mathrm{~S}$.

Published online 11 July 2017

Cite this article as: Sroka J., Kusyk P., Bilska-Zając E., Karamon J., Dutkiewicz J., Wójcik-Fatla A., Zając V., Stojecki K., Różycki M., Cencek T. 2017: Seroprevalence of Toxoplasma gondii infection in goats from the south-west region of Poland and the detection of T. gondii DNA in goat milk. Folia Parasitol. 64: 023. 